\title{
The Fruitfulness of Article 34(6) of the Protocol to the African Charter on Human and Peoples` Rights on the Establishment of an ACHPR and its Bitter Pill to State Parties.
}

\author{
BOKA Melkisedeck Lyamuya* \\ LL.B (Hons) ( Dar) \\ Advocate Candidate \\ Email: bmelkisedeck@yahoo.com
}

\begin{abstract}
In this paper a reader will be equipped with the background of the African Court on Human and Peoples' Rights “ACHPR", the relationship between ACHPR and the African Commission on Human and Peoples' Rights ${ }^{1}$, the deposition of Special Declaration by state parties granting direct access her nationals to the ACHPR and its effect thereto, the comparative analysis ACHPR and its sisters Courts, and the way forward.
\end{abstract}

\section{Introduction}

In recent years it has been witnessed a tremendous change in protecting human and peoples' rights in Africa. The African Court on Human and Peoples' Rights ${ }^{2}$ invariably its establishment ${ }^{3}$ serves as a binding authority to the state parties to the Protocol in which State parties have automatic access to the Court.

\footnotetext{
* The author is so grateful to his colleagues at the Law School of Tanzania, to his human rights law Lecturer at the Law School of Tanzania Mr. James Jesse for their assistance and industrious knowledge in human rights law.

${ }^{1}$ Hereinafter "African Commission" or "Commission."

${ }^{2}$ Hereinafter "African Court" or "Court"

${ }^{3}$ Protocol to The African Charter on Human and Peoples' Rights on The Establishment of an African Court on Human and Peoples' Rights.
} 
According to the Protocol to the African Charter on Human and Peoples' Rights on The Establishment of an African Court on Human and Peoples' Rights ${ }^{4}$ (Article 5) and the Rules ${ }^{5}$ (Rule 33), the Court may receive complaints and/or applications submitted to it either by the African Commission of Human and Peoples' Rights or by State parties to the Protocol or African Intergovernmental Organizations. Non-Governmental Organizations with observer status before the African Commission on Human and Peoples' Rights and individuals from States which have made a Special Declaration accepting the jurisdiction of the Court can also seize the African Court with applications directly before it. As of October 2013, only seven countries had made such a Special Declaration. Those countries are Burkina Faso, Ghana, Malawi, Mali, Tanzania, Rwanda, and Côte d'Ivoire. To that effect the Court shall be competent to receive cases from individuals and NGOs with observer status within the African Commission on Human and Peoples' Rights.

\section{Background of the African Court}

Ideally the journey towards the establishment of the African Court started since $1961 .^{6}$ At that time it was a subject matter of discussion in the Organization of African Unity (OAU). Unfortunately the African Charter on Human and Peoples' Rights ${ }^{7}$, the 'Banjul Charter' (ACHPR), was not signed until the OAU summit in 1981. However without doubt, the signing of Banjul Charter did not establish the African Court. Consequently the state parties agreed to establish the Commission on Human and Peoples' Rights (African Commission). Effectively it began to work from its inception 1987 a year later after the entry into force of the Banjul Charter in 1986 .

The initiative of forming the African Court was prompted undoubtedly by the tragic and shocking event of Rwanda genocide. The latter made the all of African to mourn and grieve. The

\footnotetext{
${ }^{4}$ Hereinafter "Protocol"

52010 ACHPR-RoP: 2010 Rules of Procedure of the African Court on Human and Peoples' Rights; These Internal Rules shall replace the Interim Rules of Procedure of 20 June 2008, following the harmonization of the Interim Rules of the Court and the Commission carried out during joint meetings in July 2009 in Arusha, October 2009 in Dakar and April 2010 in Arusha.

${ }^{6}$ Andreas Z. \&Jelena B., "Current Challenges facing the African Court on Human and Peoples' Rights", KAS International Reports $7 / 2010$

${ }^{7}$ Dated 27 June 1981, 1520 UNTS 217
} 
resolution $^{8}$ was passed requesting the Secretary- General to convene a Government experts' meeting to discuss the deficiency of the African Commission, with the light particular of establishing an African Court on Human and Peoples' Rights. ${ }^{9}$ As a response two meetings of Government legal experts' were held in Cape Town, South African and Nouakchott, Mauritania respectively. Further two meetings were conducted before the protocol was adopted at OAU summit in Ouagadougou, Burkina Faso, on 9 June, 1998. However it entered into force on 25 January 2004 following ratification by the Comoros. Currently the Protocol to the African Charter on Human and Peoples' Rights on the Establishment of an African Court on Human and People's Rights has been ratified and deposited by twenty six countries out of fifty four countries whereby only fifty two countries are signatory to the Protocol. ${ }^{10}$

\section{Relationship between the Court and the Commission}

\section{African Court}

As pointed above the African Court was established by the Protocol as per article 1 which plants within the Organization of African Unity (now AU) an African Court on Human and Peoples' Rights. The Court's jurisdiction and functions are governed by the present Protocol. The Court is composed of eleven judges who are coming from member states and get to be appointed on individual capacity based on academic competence, experience in legal practice and good moral character. ${ }^{11}$ The Court is given power to apply the provisions of the Charter; however it has been given a broad range to source authorities from other relevant human rights instruments ratified by the States concerned. Consequently a state party to the Charter cannot raise a defense regarding a violation of human right that the right is not provided by the Charter, if that right is provided in another instrument signed by a state party. The draftsman has made a compendium by using only a single line. The Court has discretion to consider cases or transfer them to the Commission.

\footnotetext{
${ }^{8}$ AHG/Res.230 (XXX) adopted by the Assembly Heads of state and Government in June 1994 in Tunis, Tunisia

${ }^{9} \mathrm{http} / / /$ www.africa-union.org/root/au/Documents/Treaties/Text/africancourt-humanrights.pdf accessed on 12th day of October 2013.

${ }_{10}^{10}$ Available at http://www.au.int/en/sites/default/files/achpr.pdf last visited 16/11/2013

${ }^{11}$ Article 11 of the Protocol
} 


\section{African Commission}

Under article $30^{12}$ establishes An African Commission on Human and Peoples' Rights, hereinafter called "the Commission", within the Organization of African Unity (now AU) to promote human and peoples' rights and ensure their protection in Africa. The functions of the Commission are stipulated under article $45^{13}$ inter alia it interprets all the provisions of the present Charter and ensures the protection of human and peoples' rights under the Banjul Charter. Through its advisory and non contentious jurisdiction African Commission has protected and provided a guide of advice all the way from 1986 to January 2004 in the year the African Court came into operation

The African Commission and the African Court provide a forum shopping for enforcement of human and peoples' rights. The Court complements the protective mandate of the African Commission on Human and Peoples' Rights conferred upon it by the African Charter on Human and Peoples' Rights. ${ }^{14}$ That is to say the African Court takes from the edge of the African Commission and issues binding judgments.

\section{The Bitter Pill of Article 34(6) of the Protocol to the ACHPR on the Establishment of ACHPR}

Without doubt, the establishment of this Court is a significant advance in the institutionalization of human rights in Africa. The Court comes with the prospect of strengthening the African human rights system and ensuring the protection and fulfillment of fundamental rights and duties in the continent. Yet others have cautioned that the establishment of the Court is by no means a panacea to the normative and institutional pitfalls of the African human rights system. There is a particular concern about the direct access of individuals and NGOs of observer's status with the African Commission to the Court. The direct access has been restricted or / qualified.

Individuals are the ones who are the victims of human rights violation. The Banjul Charter as a normative enshrines the rights and freedoms which are enjoyed by the individuals of state parties

\footnotetext{
${ }^{12}$ African (BANJUL) Charter on Human and Peoples' Rights (Adopted 27 June 1981, OAU Doc. CAB/LEG/67/3 rev. 5, 21 I.L.M. 58 (1982), entered into force 21 October 1986)

${ }^{13}$ supra

${ }^{14}$ Article 2 of the Protocol to The African Charter on Human and Peoples' Rights on The Establishment of an African Court on Human and Peoples' Rights
} 
without any qualification thereto. In line with the rights, the Charter shoulders the obligations to the contracting parties to respect and protect human rights in their respective jurisdictions. Besides the Banjul Charter, there are institutional provisions contained therein the Protocol which came into operation later. The Protocol merely provides a mechanism to protect those rights.

Article 3(1) of the Protocol confers jurisdiction on the Court to hear matters concerning the alleged violation of human rights; the Article reads;

"The jurisdiction of the Court shall extend all cases and disputes submitted to it concerning the interpretation and application of the Charter, this Protocol and any other relevant Human Rights instrument ratified by the States concerned".

Article 5(3) of the Protocol reads together with Article 34(6) of the Protocol sets out jurisdiction of the Court to consider the applications by individuals and NGOs

Article 5(3) reads;

"The Court may entitle relevant Non Governmental Organizations (NGOs) with observer status before the Commission, and individuals to institute cases directly before it, in accordance with article 34 (6) of this Protocol”.

Article 34(6) provides;

"At the time of the ratification of this Protocol or any time thereafter, the State shall make a declaration accepting the competence of the Court to receive cases under article 5 (3) of this Protocol. The Court shall not receive any petition under article 5(3) involving a State Party which has not made such a declaration"

The findings jotted down by the Supreme Court of Nigeria once held that, "he who cannot reach the Courts cannot talk of justice from the Courts."(Attorney General, Kaduna State v. Hassan: 1985). ${ }^{15}$ He points out that the denial of individual direct access to the Court shows lack of effective legal protection of human rights in Africa. ${ }^{16}$

\footnotetext{
${ }^{15}$ Dr. T. F. Yerima, "Comparative Evaluation of the Challenges of African Regional Human Rights Courts", Journal of Politics and Law, 2011, Vol. 4, No. 2; p.123

${ }^{16}$ Mughwai A. (2010).The Role of the African Court on Human and Peoples' Rights: Prospects and Challenges,
} 
It is undoubtedly that for individuals and NGOs of observer's status with the African Commission to have rationae personae to the African Court their contracting states need to ratify the Protocol first and then make a Special Declaration thereto. If the state has ratified the Banjul Charter and Protocol to that effect but is yet to make a Special Declaration her individuals and NGOs' locus stand is detracted. Unlike the nationals and NGOs of state parties which have made a Special Declaration, state parties which are yet to make a Special Declaration can never be draged to the African Court on account of human rights violations and that, it denies individuals direct access to the Court.

Regarding the case of Femi Falana v. The Afracan Union, Application No. 001/2011 ${ }^{17}$ the applicant is a human rights lawyer based in Lagos, Nigeria who seized the ACHPR with an application against the African Union. In his Application he avered that his Federal Republic of Nigeria has not yet make a Special Declaration as per Aricle 34(6) of the Protocol so as to confer nationals rationae personae in the ACHPR. Despite of his unsuccessfully attempts pressurising Federal Republic of Nigeria to make a Special Declaration his efforts have no avail. He alleges further he has been denied his access to ACHPR because of the failure or rather refusal of Nigeria to make a Special Declaration to accept the competence of the Court in line with Article 34(6) of the Protocol.

The Court by a majority of seven votes to three rejected his application on the ground that the African Union is legal person and is neither party to the Banjul Charter nor the Protocol henceforth cannot be subject to obligation arising either from the Banjul Charter or the Protocol unless it has been allowed to become a party to the Charter or Protocol and it is willing to do so, both of them of which do not exist at all. The Court maintains that Article 5(3) and 34(6) of the Protocol, if read together it has no jurisdiction to hear cases instituted by nationals if their countries have not complied with said Articles of the Protocol.

Further in Michelot Yogogombaye v The Republic of Senegal, Application No. 001/2008 the applicant brought an application in the ACHPR asserting that Chad and Senegal have accept the compentence of the Court by having made a Special Declaratio as per Article 34(6) of the

available at http://www.cam.es/docs/fiheros/20081003000769pdf- he says "True, denial of direct access to individuals is 'a step back' in access to justice for all in Africa."

${ }_{17} \mathrm{http} / / /$ www.africa-union.org/root/au/Documents/Treaties/Text/africancourt-humanrights.pdf accessed on 12th day of October 2013. 
Protocol which requires to confer rationae personae to individuals and NGOs. In its findings the Court found that the averments were not true and Senegal hadn't yet made a Special Declaration allowing individual to brings complaints or communication direct to the African Court of Human and Peoples' Rights.

It is observed that Article 34(6) of the Protocol does not give individuals and NGOs a direct access to the Court.The access is subject to the deposition of a Special Declaration. In my view this impedes the efforts of enforcing human rights instruments on account of a violation by a contracting party.

\section{Comparative Analysis with its Sisters Courts}

\section{The Inter-American Court of Human Rights}

The American Convention on Human Rights famous known as "Pact of San Jose" adopted on 22th November 1969 at San Jose, Costa Rica under article 33 establishes two organs. These organs are the Inter-American Commission on Human Rights, referred to as "The Commission;" and the Inter-American Court of Human Rights, referred to as "The Court." They have been vested with jurisdiction to entertain matters relating to the Convention so far as the states parties are concern.

Our very concern in this paper in relation to the Pact of San Jose is article 61(1) which reads;

"Only the States Parties and the Commission shall have the right to submit a case to the Court." Thus, the Pact of San Jose is unwilling to grant a direct access to individuals and NGOs to the Inter-American Court of Human Rights. However the Pact of San Jose under article 44 which reads;

"Any person or group of persons, or any non-governmental entity legally recognized in one or more member states of the Organization, may lodge petitions with the Commission containing denunciations or complaints of violation of this Convention by a State Party."

Thus, individuals and NGOs of states parties are deemed to have been granted indirect access to the Inter-American Court on Human Rights through the Commission. 
According to J. Symonides ${ }^{18}$ When article 44 and 51 of the Pact of San Jose are read together, after the complaint or communication held admissible by the Commission then, those individuals and or NGOs will be deemed to have been granted indirect access to the InterAmerican Court of Human Rights.

Despite the fact that the commission plays a vital role of settling disputes in a friendly and amicable manner but still the direct access to the Inter-American Court by individuals cannot be ignored ${ }^{19}$. The fact which is not denied is that the Inter- American Court of Human Rights came into existence so as to render binding judgment due to the rampant violation of human rights in America. ${ }^{20}$ In my view the role played by the Inter-American Court of Human Rights cannot be dispensed by the Commission's role.

\section{The European Court of Human Rights}

In comparison with the European Court of Human Rights ${ }^{21}$ before the restructuring of the control institutional machinery, individuals, groups of persons as well as NGOs were denied direct access. However following the restructuring under the Human Rights (Protocol No. 11), 11. V. $1994^{22}$ which came out with Article 34, thus reads;

"The Court may receive application from any person, non-governmental organisation or group of individuals claiming to be the victim of a violation by one of the High Contracting Parties of the rights set forth in he Convention or the Protocols thereto. The High Countracting Parties undertake not to hinder any way the effective exericise of this right".

Then the Protocol ${ }^{23}$ guarantees to nationals of Contracting Parties direct access to the European Court of Human Rights. It doesn't bar or rather refute its accessibility by individuals or NGOs of Member States. Unlike the African Court, the Europen Court of Human Rights cleans up its way and make it reachable by individuals and NGOs. That is to say the European Court of Human

\footnotetext{
${ }^{18}$ Director of the Department of Peace, Human Rights, Democracy and Tolerance. UNESCO; T.Buergenthal, “ The Inter-American Court of Human Rights and the OAS", Human Rights Law Journal, 1986, Vol.7

${ }_{19}$ Amy S. Dwyer, "The Inter-American Court of Human Rights: Towards Establishing an Effective Regional Contentious Jurisdiction", Boston College International \& Comparative Law Review, 1990, [Vol. XIII, No. I

${ }^{20}$ Supra.

${ }^{21}$ Established by the Convention on Protection of Human Rights and Fundamental Freedoms signed at Rome on 4 November 1950.

${ }^{22}$ to the Convention for the Protection of Human Rights and Fundamental Freedoms, Restructuring the Control Machinery Established Thereby, ETS No. 155

${ }^{23}$ to the Convention for the Protection of Human Rights and Fundamental Freedoms, Restructuring the Control Machinery Established Thereby, ETS No. 155
} 
Rights assures fully the access of nationals and NGOs and qualify as the most advanced forum of human rights protection. ${ }^{24}$

In light with the changes in the European Court of Human Rights the problem raised above in Article 34(6) water downs the intention of the African Charter on Human and Peoples' Rights hence there is a need to restructure.

The restructuring of the African Court on Human and Peaples' Rights by amending Artilce 34(6) of o Protocol to the African Charter on Human and Peaples' Rights on the Establishment of African Court on Human and Peaples' Rights is inevitable to the effect to allow a direct access by individuals and NGOs.

\section{The Fruitfulness of Article 34(6) of the Protocol to the ACHPR on the Establishment of an ACHPR}

Since the establishement of the African Court there is only one case of Tanganyika Law Society, The Legal and Human Rights Centre and Reverend C.R. Mtikila v. The United Republic of Tanzania, Application No. 011/2011 which has been decided on merits. One Rev. Mtikila his issue against the government of Tanzania started the way back in 1993. The background of the case is very interesting. It is my intention to every reader of this paper to be sufficiently familiar with. In a nutshell, One Rev. C.R. Mtikila in 1993 filed a petition before the High Court of Tanzania praying inter alia, the declaration of articles 39 and 67 of the Constitution of the United Republic of Tanzania of 1977 were unconstitutional. $^{25}$ The fact being, they bar independent candidate. The articles make a mandatory for every person in order to take part in presidential or parliamentary or local council election should join a political party. His lordship the late Mr. Justice Lugakingira delivered the remarkable jugdment in favour of the petitioner. Consequently the government being aggrieved with the decision brought a bill in the National assembly which was passed and became the law titled as the Eleventh Constitutional Amendment Act, 1994 with the effect of burying the right to independent candidate. Again one

\footnotetext{
${ }^{24}$ J. Symonides, “ Access of Individuals to International Tribunals and International Human Rights Complaints Preocedures",p. 485

${ }^{25}$ Chief Justice (rtd) Barnabas Albert Samatta, "Judicial Protection of Democratic Values: the Jugdment of the Court of Appeal of Independent Candidates", A Public Lecture delivered at Ruaha University College, Iringa, November 25, 2010.
} 
Rev. Mtikila challenged the latter amendment of the constitution before the High Court of Tanzania successfully.

The Attorney General being aggrieved with the decision of the High Court of Tanzania he appealed against it to the Court of Appeal of Tanzania. The Court of Appeal in its findings disagreed with the decision of the High Court. In cementing its decision stated that;

"The issue of independent candidates has to be settled by Parliament which has the jurisdiction to amend the Constitution and not the Courts which, as we have found, do not have that jurisdiction."

The Court of Appeal of Tanzania being the apex court to render decisions in Tanzania denied granting the right to independent candidate. Tirelessly, one Rev. Mtikila a "determinant man"26 he filed a complaint to the African Court on Human and Peoples' Rights. The latter delivered its first judgment on merits, it declared Tanzania has been breaching the African Charter and was directed to take constitutional, legislative and all other necessary measures within a reasonable time to remedy the violations found by the Court.

Being the first case to be decided on merits, it doesn't mean that there are no violation of human rights in Africa. But the problem is coilled in the mode of the operation of the African Court. To begin with, is the stringent condition on its accessibilty. Tanzanians enjoy access to the African Court simply because Tanzania has made a Special Declaration as per Article34(6) of the Protocol. How about other countries which are yet to make a Special Declaration? For example Kenya and Uganda. Their individuals are denied direct access to the African Court.

\section{Conclusion}

As pointed above the challenges and recommendations regarding the African Court on Human and Peoples' Rights are inexhastive. The African states need to go beyond the recommendations set out in these letters. A starting point should begin with an image of the European Court of Human Rights. The African Court on Human and Peoples' Rights should clean up its house before the guest arrives. As stated in the bible one should prepare the way of the Lord, make his

\footnotetext{
${ }^{26}$ Described by the High Court of Tanzania in the case of Christopher MtikilaV. The Attorney General HC at Dar es Salaam Misc. Civil Cause No. 10 of 2005, MASATI, J:
} 
paths straight. ${ }^{27}$ The Protocol on the Statute of the African Court of Justice and Human Rights ${ }^{28}$ which is not yet in operation is seeking to merge the African Court on Human and Peoples' Rights and the Court of Justice of the African Union. For the preparation of the merger of the Courts then such challenges however, trivial one may regard should be dealt positively. Under article $35^{29}$ of the Protocol permits the amendment of the present Protocol upon complying with the requirement of making a written request to that effect Secretary-General of the OAU. ${ }^{30}$ On the other way around the Court has been entitled to propose any amendments to the present Protocol as it may deem necessary, through the Secretary-General of the OAU. The recommended amendments should do away with the restrictions of direct access to African Court by individuals and NGOs with observer status with the African Commission.

\footnotetext{
${ }^{27}$ Isaiah 40:3; Matt 3:3

${ }^{28}$ Adopted by the Eleventh Ordinary Session of the Assembly, Held in Sharm El-Sheikh, Egypt, and $1^{\text {st }}$ July, 2008.

${ }^{29}$ The amendment shall come into force for each State Party which has accepted it thirty days after the SecretaryGeneral of the OAU has received notice of the acceptance.

${ }^{30}$ The Assembly may adopt, by simple majority, the draft amendment after all the States Parties to the present Protocol have been duly informed of it and the Court has given its opinion on the amendment.
} 


\section{References}

African Charter on Human and Peoples' Rights (Ratification and Enforcement) Act, Vol. 1, Cap A9, LFN, 2004. Available on http://www.au.int/en/treaties last visited, 16/11/2013

Andreas Z. \&Jelena B., "Current Challenges facing the African Court on Human and Peoples' Rights", KAS International Reports 7/2010

Amy S. Dwyer, "The Inter-American Court of Human Rights: Towards Establishing an Effective Regional Contentious Jurisdiction", Boston College International \& Comparative Law Review, 1990, [Vol. XIII, No. I

Anne Pieter V.D.M. (2005). "The New African Court on Human and Peoples' Rights: Towards an Effective Human Rights Protection Mechanism in Africa?" Vol. 18, No. 1, Leiden Journal of Intertional Law.

Anthony A.E. (1997). Beyond the Paper Tiger: The Challenge of a Human Rights Court in Africa, Texas Inter'1 Law Journal, summer, available at www.africancourtcoalition.org/content_files.Beyond the Tiger.doc. -last visited on 16/11/2013

Barnabas A. Samatta, "Judicial Protection of Democratic Values: the Jugdment of the Court of Appeal of Independent Candidates", A Public Lecture delivered at Ruaha University College, Iringa, November 25, 2010.

Buergenthal T, The American Convention on Human Rights: Illusions and Hopes, 21 BUFFALOL. REV. 121, 123-24 (1971)

Buergenthal, T. "The Inter-American Court of Human Rights and the OAS", Human Rights Law Journal, 1986, Vol.7

Christopher Mtikila V. The Attorney General HC at Dar es Salaam Misc. Civil Cause No. 10 of 2005.

C.R. Mtikila,Tanganyika Law Society, The Legal and Human Rights Centre and v. The United Republic of Tanzania, Application No. 011/2011 available at http://www.africa.court.org/en/cases/. Last visited on $16 / 11 / 2013$

Dankofa Y. (2003-2004) "Towards an Effective Safeguard for the Enforcement of Human Rights in Africa the Need for an African Court", Ahmadu Bello Univ. Law Journal, Vol. 21-22, at 83.

Femi Falana v. The Afracan Union, Application No. 001/2011 available at http://www.africa.court.org/en/cases/. Last visited, 12/11/2013

Michelot Yogogombaye v. (2009). The Republic of Senegal, Application No. 001/2008. Available at http://www.africa.court.org/en/cases/latest-judgment-05/04/2009. last visited 16/11/2013

Mughwai A. (2010).The Role of the African Court on Human and Peoples' Rights: Prospects and Challenges, available at http://www.cam.es/docs/fiheros/20081003000769pdf- . 
Protocol to the African Charter on Human and Peoples' Rights on The Establishment of an African Court on Human and Peoples' Rights available at http://www.au.int/en/treaties last visited, 16/11/2013.

Protocol and Statute of the African Court of Justice and Human Rights. (2007). available at http://www.hurisa.org.za.Advocacy/AfricanCourt/single_Legal_instrument last visited, 16/10/2013.

Symonides J., "Access of Individuals to International Tribunals and International Human Rights Complaints Procedures"

T. F. Yerima, "Comparative Evaluation of the Challenges of African Regional Human Rights Courts", Journal of Politics and Law, 2011, Vol. 4, No. 2.

The Honorable Attorney General v. Reverend C. Mtikila Civil Appeal No. 45 of 2009 CA at Dar es Salaam (Unreported).

Udombana N.J. (2000). “Towards the African Court on Human and Peoples' Rights: Better Late than Never", Yale Human Rights \& Development Law Journal.

Udombana N.J. (2003) "The Local Remedies Rule in the Jurisprudence of the African Commission on Human and Peoples' Rights", the American Journal of International Law [Vol. $97: 1$ 